\title{
THE QUANTITATIVE EXTRACTION OF DIASTASES FROM PLANT TISSUES.
}

By R. W. Thatcher and Geo. P. Koch.

Received February 6, 1914.

There are two different opinions as to the nature of enzyme action. One supposes that enzymes are only catalytic in their effect, that is, that they are only accelerators of reactions which actually occur in the absence of the enzyme, but at a very much slower rate. The other holds that enzymes are actual causative agents for their specific reactions, and function by forming definite chemical unions with the initial substance which later break down into a new substance or substances, liberating the enzyme unchanged and in condition to repeat the process an indefinite number of times. Whatever may be the nature of their action, however, it is obvious that they do not participate quantitatively in the reaction which is their specific function. Hence, they cannot be measured quantitatively by the usual methods of determining the quantity of the endproducts of the reaction. It is necessary, instead, to measure their effect upon the velocity of the reaction.

In any comparative study of the enzymes of different samples of vegetable materials, it becomes desirable to obtain comparable measures of the quantity of enzyme present. Since there are no known methods for isolating and determining the exact quantity of an enzyme in any given plant or animal tissue and, further, since in the present state of knowledge concerning enzyme action it is uncertain whether the same actual quantity of the same enzyme from different sources will possess the same accelerating or causative effect upon its substrate, the investigator is necessarily forced to assume that the comparative accelerating effect upon reactionvelocity of the extract from the same quantity of the materials under investigation is a comparable measure of the quantity of enzyme present in each sample. Or he may, as is doubtless a better procedure, use as his basis of comparison the "diastatic strength" or some similar term, instead of the actual quantity of enzyme present.

In a series of investigations of the various factors which may influence what is called the "strength" of wheat flour, we have undertaken a study of the enzymes of the wheat kernel and their distribution to the various products separated from it in milling, and of their effect upon the flour during the fermentation of the dough and baking of the loaf of bread. Quite naturally, we first sought to study the diastatic enzymes, that is, those which cause or accelerate the hydrolysis of starch. We were immediately confronted by the lack of a method of quantitative extraction of the active diastases of different samples, which would yield comparable results. There was, first, the question of a suitable standard of measurement of the acceleration of starch-hydrolysis due to the presence 
of the enzyme, and second, the difficulty of extracting an active hydrolyzing enzyme from a material containing large quantities of the hydrolyzable material, without getting continuous activity of the enzyme during the extraction period. This latter difficulty had led a number of investigators who had previously attempted a study of this kind to abandon it as incapable of exact solution, since they found that the activity of the enzyme during the extraction "used up" variable proportions of its accelerating effect, and, consequently, they obtained extracts of variable "diastatic strength" from the same sample if the time or temperature of extraction, the ratio of solvent to material, or the conditions of preservation of the extract until its "diastatic strength" could be measured, varied in even comparatively slight degrees. It occurred to us, however, that this difficulty might easily be overcome by carrying out the extraction at a temperature below that at which the enzymes exert any influence upon reaction velocity, say at $0^{\circ}$, provided the enzymes themselves were sufficiently soluble at that temperature to permit the securing of comparably quantitative extractions. This could, of course, be easily ascertained experimentally.

There remained the question of a suitable standard of measurement of the comparative accelerating effect of extracts from different samples. The possibility of comparable measurements depends upon whether the velocity of the reaction is uniform throughout its duration, exhibiting the so-called "straight-line" curve of reaction-velocity, or is modified by the law of mass action, having an approximately logarithmic velocitycurve. In the latter event, it would be impossible to make comparisons of velocity-accelerations of extracts from different samples, as the relative mass of hydrolyzable material and of activating enzyme in each different extract would rarely, if ever, be the same. However, Kjeldahl's first assimption ${ }^{1}$ that the amount of reducing sugar produced is a true measure of diastatic power, provided that not more than $40 \%$ of the original starch is converted into maltose at the expiration of the period of digestion, has been accepted as a working basis by many investigators and has been indirectly confirmed by Brown and Glendinning, ${ }^{2}$ who found that equal amounts of starch were hydrolyzed by diastase in equal times during the earlier part of the reaction, but that toward its close, when the concentration of enzyme becomes large as compared with that of the substrate, the reaction obeys the law of mass action. Kjeldahl's "law of proportionality" was, therefore, accepted as a suitable basis of measurement for our work.

The next question was as to the method of measurement of the velocity of the reaction. Several methods for this have been suggested.

${ }^{1}$ See Dingler's polytechn. $J$., 235, 379-387, 452-460 (I880).

$2 J$. Chem. Soc., 81, 388-392 (1902). 
Kjeldah ${ }^{1}$ recommended the determination of the amount of reducing sugar produced by the action of a definite amount of the extract in question upon an excess of starch for a definite length of time at a definite temperature.

Roberts ${ }^{2}$ proposed the use of the number of cubic centimeters of a standard starch paste which would be converted into non-iodine-coloring material in five minutes at $40^{\circ}$ by one cubic centimeter of the extract under examination, as a standard.

Jungk $^{3}$ recommended measuring the time required for Io $\mathrm{cc}$. of extract, acting at $40^{\circ}$, to convert ro $\mathrm{g}$. of anhydrous starch into maltose.

Lintner ${ }^{4}$ modified the Kjeldahl process so as to make it possible to calculate the diastatic strength upon the basis of the production of a constant quantity of maltose from a constant amount of soluble starch, expressing the "diastatic strength" of the extract in terms of percentage of the strength of a standard diastase, of which $0.12 \mathrm{mg}$., acting upon a definite quantity of soluble starch for I hour at $2 I^{\circ}$, produced enough maltose to completely reduce $5 \mathrm{cc}$. of Fehling's solution.

Johnson ${ }^{5}$ published a new form of the method, in which the amount of diastase necessary to digest a fixed amount of starch to no color with iodine in ten minutes at a temperature of $40^{\circ}$ was determined. He found that the same measure of the velocity of reaction was obtained in this way as by a measurement of the quantity of sugar produced.

Various other modifications of the Lintner process have been suggested from time to time and have recently been submitted to critical review by Sherman, Kendall, and Clark, ${ }^{6}$ who recommended, as a result of their studies, the general adoption of 30 minutes as the time and $40^{\circ}$ as the temperature for all digestions for the determination of diastatic strength. Their investigations included comparisons of reaction-velocities as measured by the disappearance of iodine-coloring material and by the quantity of maltose produced. Later and more extensive studies of these two methods of estimation of diastatic strength by Sherman and Schlesinger ${ }^{7}$ emphasize the distinction between the amyloclastic and the saccharogenic activity of diastatic preparations and point out the relationships which exist between these, and some of the advantages and disadvantages of the two processes.

For the purposes of our investigations, it was very clearly the sugarproducing, or saccharogenic, power of the diastases of flour which it would

${ }^{1}$ Loc. cit.

2 Proc. Roy. Soc., 32, 145-161; abs. in J. Chem. Soc., 40, 105 I (1881).

3 Pharm. J. Trans., [3] I4, 104-108; abs. in J. Chem. Soc., 46, 529-53 I (1884).

4 J. prakt. Chem., [2] 34, 378-394 (I886).

- This Journal, 30, 798-805 (I908).

'Ibid., 32, 1073-1086 (1910).

${ }^{7}$ Ibid., 35, I 784-1790 (1913). 
be of value to study, and we, therefore, decided to use the maltose produced by digestion at $40^{\circ}$ for 30 minutes as themeasure of the reaction velocity or the "diastatic strength" of the extracts from the samples under investigation.

As a rapid and accurate method of measuring the maltose produced, the determination of the residual copper, after boiling a suitable aliquot portion of the solution with a definite volume of standardized Fehling's solution, by titration by the iodine method, as perfected by Peters, ${ }^{1}$ seemed promising, and upon trial proved thoroughly satisfactory.

The process of preparing the portion of the extract used as a blank, and the solutions after digestion with soluble starch, for their action upon the standardized Fehling's solution was that used by Swanson and Calvin in their investigation of the conditions affecting the activity of the amylolytic enzymes in wheat flour, ${ }^{2}$ and was found to work very satisfactorily.

\section{Experimental Data.}

The object of this preliminary work was to ascertain whether the diastases present in wheat-products could be quantitatively extracted at $0^{\circ}$, in order that none of their catalytic power might be "used up" during the process of dissolving them from the material under investigation The plan of the work involved the digestion of weighed quantities of ground wheat, bran, and different grades of flour in water at $0^{\circ}$ for varying lengths of time and the determination of the maltose-producing power of the resultant extracts. It was believed that, if the results should show a uniform diastatic power for extracts made at different lengths of time, and a uniform quantity of reducing sugars in the aliquot part of the extract used as a blank, the principle that the diastases are quantitatively extracted, and that no diastatic action occurs during the extraction at that temperature, would be established.

In order to facilitate computations of fractions resulting from taking aliquot parts, we decided to use I6 g. of material for each extraction. Swanson and Calvin ${ }^{3}$ found that the maximum amylolitic activity was secured when flour and water were used in proportions varying from I : 4 up to I : ro. We, therefore, decided to use $200 \mathrm{cc}$. of water for each extraction, this being a convenient volume for subdivision and not far outside the optimum limits just mentioned.

Ordinary half-pint milk sample bottles were used to hold the materials during the extraction. These bottles were furnished with a tin cap held down by a spring clamp. To insure against leakage, a disk cut from thin rubber was placed under the cap before it was clamped down. In preparing the material for extraction, the charge of dry material was

${ }^{1}$ See This Journal, 34, 433-452 (19:2).

2 Ibid., 35, 1636-1637 (1913).

${ }^{3}$ Loc. cit. 
weighed into the bottle, the cover clamped down and the bottle placed in the ice-water bath until its contents reached the desired temperature. The bottle was then removed from the bath, its stopper loosened, and $200 \mathrm{cc}$. of redistilled water (previously cooled to $0^{\circ}$ ) quickly pipetted into it. The cap was again clamped down and the bottle immediately returned to the ice-water bath. The filling of the several bottles of each series was so timed that all the desired periods of extraction would terminate at the same time, in order that all subsequent operations upon the extracts might be carried on simultaneously. Each bottle was shaken vigorously at intervals during the extraction.

At the expiration of the extraction period, the bottles were removed from the bath and their entire contents quickly poured upon large $S$ and $S$ folded filters. The first few drops which came through were usually cloudy, but by pouring back once or twice a filtrate clear enough for all practical purposes was easily obtained. Filtration was usually rapid enough so that a sufficient volume of extract for the necessary aliquots could be obtained in a few minutes and without serious rise in temperature of the extract. (In working with materials which filter slowly the temperature might be kept down by placing the funnel in a jacket, such as is used for hot filtration, filled with ice-water; but this was not found necessary in any of our work.) As soon as a sufficient volume of extract was secured, it was at once warmed to $40^{\circ}$, the temperature at which its action upon starch was to be ascertained, and two aliquots of $50 \mathrm{cc}$. each drawn out. To one of these $\mathrm{N} /$ ro sulfuric acid was added, in such an amount that the resultant mixture would be a $0.02 \mathrm{~N}$ solution (this being the strength found by Swanson and Calvin to be the correct one) in order to stop all diastatic action. To the other aliquot, $25 \mathrm{cc}$. of a 10\% solution of soluble starch (previously warmed to $40^{\circ}$ ) were added, and the mixture placed in an incubator, kept automatically at $40^{\circ}$, for exactly 30 minutes. At the expiration of this time, further action was stopped by bringing the mixture to a $0.02 \mathrm{~N}$ sulfuric acid. In both the blank and the digested solution, the soluble proteins were precipitated with salt and phosphotungstic acid, and the maltose in an aliquot of each determined, by the methods mentioned above. The results obtained in the first series of experiments, using ground wheat, ground barley, bran, and three different grades of wheat flour, calculated to the basis of $\mathrm{I} g$. of original material in each case, are shown in Table $I$.

As a further confirmation that the diastases were quantitatively extracted from materials such as those under examination by diffusion into water at $0^{\circ}$, we conducted another series of extractions using in each case, first, the material ground as for ordinary analyses, and, second, the same weight of material after grinding vigorously for ten minutes in a mortar with an equal weight of sharp quartz sand. It would seem that 
Table I.-Showing EfFect of Different Lengths of Time of Extraction at $0^{\circ}$ upon Diastatic Strength of Extract.

(I6 g. material, $200 \mathrm{cc}$. water, $50 \mathrm{cc}$. aliquots used.)

Resuits calculated to $1 \mathrm{~g}$. material.

\begin{tabular}{|c|c|c|c|c|c|}
\hline Material. & $\begin{array}{l}\text { Time of } \\
\text { extraction. } \\
\text { Hours. }\end{array}$ & $\begin{array}{l}\text { Copper re- } \\
\text { duced after } \\
\text { digestion. } \\
\text { Gram. }\end{array}$ & $\begin{array}{c}\text { Copper } \\
\text { reduced } \\
\text { by blank. } \\
\text { Gram. }\end{array}$ & $\begin{array}{l}\text { Copper } \\
\text { due to } \\
\text { enzyme. } \\
\text { Gram. }\end{array}$ & $\begin{array}{c}\text { Maitose } \\
\text { equivalent. } \\
\text { Gram. }\end{array}$ \\
\hline \multirow[t]{3}{*}{ Wheat. . } & . . 5 & 0.454 & 0.023 & $0.43 \mathrm{I}$ & 0.339 \\
\hline & 3 & 0.422 & 0.016 & 0.406 & 0.319 \\
\hline & I & 0.422 & 0.014 & 0.408 & 0.320 \\
\hline \multirow[t]{3}{*}{ Barley... } & 5 & 0.474 & 0.038 & 0.436 & 0.342 \\
\hline & 3 & 0.465 & 0.036 & 0.429 & 0.337 \\
\hline & I & $0.45 \mathrm{I}$ & 0.023 & 0.428 & 0.336 \\
\hline \multirow[t]{3}{*}{ Bran. } & 5 & 0.468 & 0.008 & 0.460 & 0.362 \\
\hline & 3 & 0.434 & 0.005 & 0.429 & 0.337 \\
\hline & $x$ & $0.45 I$ & 0.005 & 0.446 & $0.35 \mathrm{I}$ \\
\hline \multirow[t]{3}{*}{ Patent flour. } & 5 & 0.439 & 0.015 & 0.424 & 0.334 \\
\hline & 3 & $0.45 \mathrm{I}$ & 0.013 & 0.438 & 0.344 \\
\hline & I & 0.477 & 0.013 & 0.464 & 0.365 \\
\hline \multirow[t]{3}{*}{ First clear four. . } & 5 & 0.445 & 0.013 & 0.432 & 0.339 \\
\hline & 3 & 0.436 & 0.007 & 0.429 & 0.337 \\
\hline & $I$ & 0.425 & 0.005 & 0.420 & 0.330 \\
\hline \multirow[t]{3}{*}{ Second clear flour. } & $\cdots 5$ & 0.477 & 0.024 & 0.453 & 0.356 \\
\hline & 3 & 0.474 & 0.012 & 0.462 & 0.363 \\
\hline & I & $0.47 \mathrm{I}$ & 0.007 & 0.464 & 0.365 \\
\hline
\end{tabular}

by this vigorous treatment the cell tissues would be so thoroughly ruptured that there could be no possible danger of incomplete solution of the diastases. Two check samples, prepared in this way, of several different materials were treated with water at $0^{\circ}$ for $\mathrm{I}^{1} / 2$ hours and the diastatic strength of the resultant extracts determined as before, with the results shown in Table II.

Table II.-Showing EFFect of Grinding Material with Sand upon Diastatic StrEngth OF Extract.

\begin{tabular}{|c|c|c|c|c|c|}
\hline \multirow[b]{2}{*}{ Material. } & \multirow[b]{2}{*}{$\begin{array}{c}\text { Mode of } \\
\text { preparation. }\end{array}$} & \multicolumn{4}{|c|}{ Results calculated to $1 \mathrm{~g}$. material. } \\
\hline & & $\begin{array}{l}\text { Copper re- } \\
\text { duced after } \\
\text { digestion. } \\
\text { Grams. }\end{array}$ & $\begin{array}{l}\text { Copper } \\
\text { rediced } \\
\text { by blank. } \\
\text { Gram. }\end{array}$ & $\begin{array}{l}\text { Copper } \\
\text { due to } \\
\text { enzyme. } \\
\text { Grams. }\end{array}$ & $\begin{array}{l}\text { Maltose } \\
\text { equivalent. } \\
\text { Grams. }\end{array}$ \\
\hline Barley & $\begin{array}{l}\text { ordinary } \ldots \ldots \ldots \ldots \ldots \ldots \\
\text { ground with sand.......... }\end{array}$ & $\begin{array}{ll} & 0.459 \\
\ldots & 0.474\end{array}$ & $\begin{array}{l}0.020 \\
0.015\end{array}$ & $\begin{array}{l}0.439 \\
0.459\end{array}$ & $\begin{array}{l}0.345 \\
0.361\end{array}$ \\
\hline Wheat & $\begin{array}{l}\text { ordinary } \ldots \ldots \ldots \ldots \ldots \ldots \\
\text { ground with sand } \ldots \ldots \ldots\end{array}$ & $\begin{array}{ll}\text {. } & 0.498 \\
\ldots & 0.477\end{array}$ & $\begin{array}{l}0.023 \\
0.023\end{array}$ & $\begin{array}{l}0.475 \\
0.454\end{array}$ & $\begin{array}{l}0.373 \\
0.357\end{array}$ \\
\hline Flour & $\begin{array}{l}\text { ordinary } \ldots \ldots \ldots \ldots \ldots \ldots \\
\text { ground with sand } \ldots \ldots \ldots\end{array}$ & $\begin{array}{ll}\text {. } & 0.449 \\
\text {. } & 0.436\end{array}$ & $\begin{array}{l}0.015 \\
0.015\end{array}$ & $\begin{array}{l}0.434 \\
0.42 \mathrm{I}\end{array}$ & $\begin{array}{l}0.341 \\
0.331\end{array}$ \\
\hline Shorts & $\begin{array}{l}\text { ordinary } \ldots \ldots \ldots \ldots \ldots \ldots \\
\text { ground with sand } \ldots \ldots \ldots\end{array}$ & $\begin{array}{ll}\ldots & 0.965 \\
\ldots & 0.907\end{array}$ & $\begin{array}{l}0.012 \\
0.020\end{array}$ & $\begin{array}{l}0.953 \\
0.887\end{array}$ & $\begin{array}{l}0.736 \\
0.682\end{array}$ \\
\hline Malt & $\begin{array}{l}\text { ordinary } \ldots \ldots \ldots \ldots \ldots \\
\text { ground with sand } \ldots \ldots \ldots\end{array}$ & $\begin{array}{l}.8 .433 \\
\ldots 8.433\end{array}$ & $\begin{array}{l}0.033 \\
0.035\end{array}$ & $\begin{array}{l}8.400 \\
8.398\end{array}$ & $\begin{array}{l}6.460 \\
6.459\end{array}$ \\
\hline
\end{tabular}


These data clearly indicate a complete extraction of active diastases at $o^{\circ}$. The diastatic strength of the extracts obtained after grinding with sand was sometimes slightly greater and sometimes slightly less than that from the sample prepared in the ordinary manner, indicating that the differences were due to lack of uniformity in the original samples and not to unequal extraction of the active diastases. In other work on similar samples, we were able to make these differences almost completely disappear by long-continued mixing of the material before weighing out samples for the determinations. The extractions for five hours show sometimes a slightly higher, and sometimes a slightly lower, activity than those for one or three hours, indicating that these differences are due to slight variability in the sample or some similar cause, and not to the length of time of extraction.

In each case, a slightly larger amount of reducing sugar was found in the blanks from the longest period of extraction. This might be due either to slight hydrolysis of starch during the extraction, or to slow solution of the reducing sugars in water at this low temperature. It was later ascertained that the sugar in the blank would vary if the proportion of water to material used were varied, while the diastatic activity per gram of material remained practically constant, even though the dilution were doubled or tripled. This clearly indicates that the variation in reducing sugars in the blank is due to gradual solution of the sugars in the material at the low temperature used, and not to diastatic action during the extraction. Further, it was found that the filtered extract could be kept for some hours at the temperature of ice-water without any increase in its sugar content, indicating either that there is no diastatic action at this temperature or that no soluble carbohydrates which can be hydrolyzed by the enzymes present are extracted from these materials at $0^{\circ}$.

In order to be certain that the maltose found was wholly due to diastatic activity, and not to hydrolysis by reagents used in the process or to any other catise, another set of extractions for varying lengths of time was made, using the same samples of ground wheat and barley as in the first series. The only variation in the process was that, just before taking the aliquots of the filtered extract for estimation of its diastatic strength, it was boiled for Io minutes. The results obtained are shown in Table II.

TABIE III.-Showing EFFEct of BoIling Extracts upon their Diastatic STRENGTH.

\begin{tabular}{|c|c|c|c|}
\hline Material. & $\begin{array}{l}\text { Time of } \\
\text { extraction. } \\
\text { Hours. }\end{array}$ & $\begin{array}{l}\text { Copper reduced } \\
\text { by blank. } \\
\text { Gram. }\end{array}$ & $\begin{array}{l}\text { Copper reduced by solution } \\
\text { from boiled extract digested } \\
\text { with } 2.5 \mathrm{~g} \text {. starch. Gram. }\end{array}$ \\
\hline \multirow{2}{*}{ Barley. } & $\ldots 2$ & 0.033 & 0.030 \\
\hline & I & 0.030 & 0.029 \\
\hline \multirow[t]{2}{*}{ Wheat. } & 2 & 0.010 & 0.011 \\
\hline & I & 0.009 & 0.010 \\
\hline
\end{tabular}


These results prove conclusively that the hydrolysis of starch to maltose, during the digestion for 30 minutes at $40^{\circ}$ in the first series of experiments, was due to the presence of diastases in the extracts under investigation.

Satisfactory results having been obtained with barley and wheat products, it was decided to study the applicability of the process to barley malt. Since malt would certainly contain larger proportions of active diastases than the other materials which had been studied, it was obvious that smaller original weights of material or smaller aliquots of the extract, or both, would have to be used in order to keep a sufficient excess of hydrolyzed starch in the mixture during the digestion period. Several preliminary trials resulted in complete hydrolysis of the starch, even when as much as $5 \mathrm{~g}$. of soluble starch were used with comparatively small aliquots of the extracts. Finally, a new set of extracts was made, using $8 \mathrm{~g}$. malt to $200 \mathrm{cc}$. water, and a series of mixtures containing $2.5 \mathrm{~g}$. of starch and $\mathrm{I}$ cc., 2 cc., 5 cc., and ro cc. of the extract, respectively, were digested at $40^{\circ}$ for 30 minutes and the resulting solutions tested with iodine. The solution containing ro $\mathrm{cc}$. of extract gave no color, that with $5 \mathrm{cc}$. a puplish red, and those with $2 \mathrm{cc}$. and $\mathrm{x}$ cc. a clear blue. It appeared from this that the limit of the reaction would not be reached by using $5 \mathrm{cc}$. of the extract from this particular sample of malt and that $2 \mathrm{cc}$. of extract would probably bring the conditions within the limits required to insure the operation of "Kjeldahl's law of proportionality."

Accordingly, extractions were made at $0^{\circ}$ for varying lengths of time, and in varying volumes of mixture of malt and water, upon two different samples of malt, and digestions of varying aliquots of the resultant extracts with starch carried on as described above. Some typical results of these determinations are presented in Table IV.

In connection with these data, attention should be called to the fact that the very large amount of maltose produced by the action of a very small aliquot of the original extract made it necessary to use a very small fraction of the final solution for the reduction with Fehling's solution. The aliquot of the residual copper solution which was finally titrated with thiosulfate solution corresponded to from $0.0 \mathrm{I} g$. to 0.00625 g. of original malt. Consequently, any slight variation in reading the end point was magnified from roo to 160 times in calculating the results to the basis of $\mathrm{I} g$. of malt.

With this fact in mind, the data in the table clearly show that complete extraction of the enzymes is obtained in a period of one hour or longer. In no case did the three-hour or five-hour extractions give significantly greater "diastatic strength," as shown by the maltose equivalent of I g. malt, than was obtained by extracting for only one hour. In some cases, the maltose equivalent was slightly higher in the one-hour extract than in those of longer periods, indicating that the differences 
were due to experimental error in making the solutions, or to slight variations in composition of the malt. In those cases where the extraction period was shortened to 30 minutes, one of which is included in the table, somewhat lower diastatic strength was always obtained, than in the longer extractions carried on under otherwise identical conditions. It appears, therefore, that this period of extraction is not quite sufficient for complete solution of the diastatic enzymes from materials ground to the customary fineness for analysis.

Table IV.-Showing Results of Application of Proposed Method to Estimation of Diastatic Strength of Barley MalT.

\begin{tabular}{|c|c|c|c|c|c|c|c|c|}
\hline \multirow[b]{2}{*}{$\begin{array}{c}\text { Sample } \\
\text { No. }\end{array}$} & \multirow[b]{2}{*}{$\begin{array}{l}\text { Weight } \\
\text { taken. } \\
\text { Granns. }\end{array}$} & \multirow[b]{2}{*}{$\begin{array}{l}\text { Water } \\
\text { used. } \\
\text { Ce. }\end{array}$} & \multirow[b]{2}{*}{$\begin{array}{c}\text { Time } \\
\text { of } \\
\text { extrac- } \\
\text { tion. } \\
\text { Hours. }\end{array}$} & \multirow[b]{2}{*}{$\begin{array}{c}\text { Aliquot } \\
\text { of ex- } \\
\text { tract. } \\
\text { used. } \\
\text { Cc. }\end{array}$} & \multicolumn{4}{|c|}{ Results calculated to $1 \mathrm{~g}$. malt } \\
\hline & & & & & $\begin{array}{l}\text { Copper } \\
\text { reduced } \\
\text { after } \\
\text { digestion. } \\
\text { Grams. }\end{array}$ & $\begin{array}{c}\text { Copper } \\
\text { reduced } \\
\text { by } \\
\text { blank. } \\
\text { Grams. }\end{array}$ & $\begin{array}{l}\text { Copper } \\
\text { due to } \\
\text { enzyme. } \\
\text { Grams. }\end{array}$ & $\begin{array}{c}\text { Maltose } \\
\text { equiva- } \\
\text { lent. } \\
\text { Grams. }\end{array}$ \\
\hline \multirow[t]{4}{*}{ I } & 8 & 200 & 5 & 5 & 8.330 & 0.090 & 8.240 & 6.300 \\
\hline & 8 & 200 & 3 & 5 & 8.120 & 0.085 & 8.035 & 6.140 \\
\hline & 8 & 200 & I & 5 & 8.120 & 0.085 & 8.035 & 6.140 \\
\hline & 8 & 200 & $1 / 2$ & 5 & 7.670 & 0.070 & 7.600 & 5.820 \\
\hline \multirow[t]{3}{*}{ I } & 4 & 100 & 5 & 5 & 7.840 & 0.090 & 7.750 & $5 \cdot 940$ \\
\hline & 4 & 100 & 3 & 5 & $7 \cdot 950$ & 0.085 & 7.865 & 6.010 \\
\hline & 4 & 100 & I & 5 & 8.060 & 0.085 & 7.975 & 6.120 \\
\hline \multirow[t]{3}{*}{ I } & 4 & 100 & 5 & 2 & Io. 640 & 0.090 & 10. 550 & 8.170 \\
\hline & 4 & 100 & 3 & 2 & 10.260 & 0.085 & I0. 175 & 7.865 \\
\hline & 4 & 100 & I & 2 & 10.080 & 0.085 & 9.995 & $7 \cdot 730$ \\
\hline \multirow[t]{3}{*}{ I } & 4 & 100 & 5 & $2+3^{*}$ & 8.625 & 0.090 & 8.535 & 6.570 \\
\hline & 4 & 100 & 3 & $2+3^{*}$ & 8.510 & 0.085 & 8.425 & 6.485 \\
\hline & 4 & 100 & I & $2+3^{*}$ & 8.510 & 0.085 & 8.425 & 6.485 \\
\hline \multirow[t]{3}{*}{2} & 16 & 200 & 5 & 2 & 2.620 & $0.15^{\circ}$ & 2.470 & I. 935 \\
\hline & I6 & 200 & 3 & 5 & 2.042 & o. 142 & I. 900 & I. 485 \\
\hline & I6 & 200 & I & 5 & 2.097 & 0.117 & I. 980 & I. 549 \\
\hline
\end{tabular}

It will be noted that the maltose equivalent per gram of sample was considerably higher when only $2 \mathrm{cc}$. of the extract were used for the digestion than when $5 \mathrm{cc}$. were used. This is in harmony with the results of Brown and Glendinning and the assumption of Kjeldahl mentioned in an earlier part of this paper. Evidently, $5 \mathrm{cc}$. of these extracts hydrolyzed the starch used past the limit of $60 \%$ of unchanged starch considered by Kjeldahl as necessary to insure the operation of the "law of proportionality." Further confirmation of this fact is found in the series in which the starch was first digested for 30 minutes with $2 \mathrm{cc}$. of extract, then $3 \mathrm{cc}$. more of extract added and the digestion continued for another 30 minutes. The maltose obtained in this way exceeded that obtained by using $5 \mathrm{cc}$. for 30 minutes, but did not nearly approach the equivalent

${ }^{*} 2 \mathrm{cc}$. digested 30 minutes, then $3 \mathrm{cc}$. additional added and digested again for 30 minutes. 
amount per gram of malt obtained when only 2 cc. of extract acted for 30 minutes on the same amount of starch.

Since the extracts obtained by treating these various materials with water at $0^{\circ}$ obey all the known laws of diastatic action, and since the diastatic strength of the extracts, as measured by maltose produced from a large excess of starch, is the same whether the extraction be continued for one, three, or five hours, we conclude that this method of operation insures a quantitative extraction of the diastases present in vegetable tissues ground to the customary degree of fineness for ordinary analyses. We plan to use this method in our further investigations, and suggest it for trial by other workers engaged in similar studies.

\section{Directions for Use of the Proposed Method.}

Prepare the sample whose diastatic strength is to be tested in the same way as for any of the common analytical processes. Weigh a suitable charge, preferably i 6 grams or some even fraction thereof, into an $8 \mathrm{oz}$. wide-mouthed bottle having a water-tight stopper, and immerse the bottle and its contents in ice-water until its temperature reaches approximately $0^{\circ}$. Pipet into the bottle $200 \mathrm{cc}$. of pure distilled water (redistilled if necessary to insure complete freedom from acid or salts) previously cooled to $o^{\circ}$. Stopper the bottle tightly and immerse it in ice-water for one to two hours, shaking vigorously at fifteen-minute intervals. At the expiration of the extraction, pour the contents of the bottle quickly upon a large folded filter, pouring back the first few cubic centimeters of cloudy filtrate until the extract comes through fairly clear (a perfectly clear filtrate at this point is not absolutely necessary). If filtration should be so slow as to make any considerable rise in temperature of the contents of the filter or of the filtrate probable, place the funnel in a waterjacket filled with ice-water and immerse the receiver in ice-water.

The diastatic strength of the extract should preferably be determined at once. If this is not convenient, however, the extract must be kept at a temperature of approximately $0^{\circ}$ until the operator is ready to proceed.

In working with materials rich in diastatic enzymes, it is desirable to make a preliminary test of the approximate amount of starch which will be hydrolyzed by various aliquots of the extract when digested under the standard conditions, in order that the final determination of maltoseproducing power may be made with such proportions of volume of extract and starch that not more than $40 \%$ of the starch taken will be hydrolyzed during the digestion period. This preliminary test is easily made by measuring the same volume of starch solution that is to be used in the final digestion into each of several test tubes, warming these to $40^{\circ}$ then adding varying volumes, say $\mathrm{I} \mathrm{cc}$, $2 \mathrm{cc}$., $5 \mathrm{cc}$., and $10 \mathrm{cc}$. of the extract, and carrying on the digestion for 30 minutes at $40^{\circ}$. At the end of this time, the solutions are tested with iodine and the one which gives just 
a faint trace of blue color is regarded as showing the approximate limit of starch-hydrolyzing power of the extract. For the final determination, a volume of extract amounting to approximately $40 \%$ of that found as this limit in the preliminary test should be used.

To determine the maltose-producing power of the extract, first warm the starch solution which is to be used ${ }^{1}$ to $40^{\circ}$, then pipet the volume of it which corresponds to 2.5 grams of anhydrous starch into a roo cc. graduated flask. Place this flask in the constant temperature oven kept at $40^{\circ}$. Now warm the extract quickly to $40^{\circ}$ and pipet the proper volume of it, as found by preliminary test, or $25 \mathrm{cc}$. in the case of the common cereals, into the flask containing the starch. Place this flask in the constant temperature oven and immediately pipet another aliquot of the extract into a graduated flask and add standard sulfuric acid to it in such a quantity that when filled to the mark the solution will be $0.02 \mathrm{~N}$ acid. This solution then constitutes the blank for the determination of reducing sugars already present in the extract. At the expiration of exactly 30 minutes from the addition of the extract to the starch solution, remove the flask from the oven and immediately stop the action by adding sulfuric acid of such strength and amount that the solution when brought to the mark will be $0.02 N$ acid.

To determine the amount of reducing sugars present in the blank and in the digested starch-extract mixture, cool both to room temperature and see that they are made just to the $100 \mathrm{cc}$. mark; then draw off $50 \mathrm{cc}$. of each solution and transfer it to another roo cc. flask; add $25 \mathrm{cc}$. of a $4 \%$ solution of salt and $5 \mathrm{cc}$. of a $10 \%$ solution of phosphotungstic acid, make to the mark and shake vigorously. This precipitates the soluble proteins which would otherwise affect the Fehling's solution. After standing a few minutes the precipitate usually settles, leaving a clear supernatant liquid, an aliquot of which can be drawn off for the estimation of its reducing sugar content; if it does not settle clear, it must be filtered through a quantitative filter before taking aliquots.

The Fehling's reduction may conveniently be carried out in a $200 \mathrm{cc}$. graduated flask, in order to avoid the necessity of filtering and washing the precipitated cuprous oxide. The small volume occupied by the precipitate does not appreciably affect the volume of liquid in the flask, so that an aliquot may be taken for titration of the residual copper. Measure accurately into the flask $25 \mathrm{cc}$. of the Fehling's copper solution, add $25 \mathrm{cc}$. of the alkaline tartrate solution and $50 \mathrm{cc}$. of water; heat to boiling and then add $25 \mathrm{cc}$. of the clear filtrate from the protein-precipitation of the solutions under investigation; bring again to boiling and boil for exactly 2 minutes. At the expiration of the 2 minutes, add cold water nearly to

1 For the method of preparing soluble starch suitable for this purpose, see the article by Sherman and Kendall previously referred to. 
the mark and cool the contents of the flask quickly to room temperature and complete the volume to $200 \mathrm{cc}$. and mix thoroughly. After standing a few minutes the precipitate settles so clearly that $50 \mathrm{cc}$. of the clear supernatant liquid can usually be pipetted off for titration of the copper which it contains; or the supernatant liquid may be poured through a quantitative filter and $50 \mathrm{cc}$. of the filtrate pipetted for the titration. The titration should be carried out as recommended by Peters in the article referred to above. At the same time, another $25 \mathrm{cc}$. of Fehling's solution should be accurately measured into another $200 \mathrm{cc}$. flask, the volume made up to the mark, and a $50 \mathrm{cc}$. aliquot pipetted out and titrated for its copper content: The difference between the thiosulfate used for the titration of this $50 \mathrm{cc}$. and that obtained from the reduction by the solution under investigation gives the thiosulfate equivalent of one-fourth of the copper reduced by the sugar in the aliquot used for the reduction. From these data the maltose content of the digested solution can be computed. From this should be deducted the reducing sugars, calculated as maltose, found in the blank from the same volume of extract as was used for the starch digestion. This gives the maltose produced by the action of the diastases in the volume of extract used. The equivalent amount of maltose reduced by the extract from I gram of material can then be calculated, or the data used to calculate the "diastatic strength" of the material to any other basis of comparison which may be selected.

Division of Agricutural Chemistry,

Agr. Expt. Station, St, Paul, MinN.

\section{THE ELIMINATION AND RETENTION OF ARSENIC AS DETER- MINED BY THE KOCH-NORTON METHOD.}

By R. Adams Dutcher and Matthew Stefl.

Received January 14, 1914.

A great majority of the investigational work on arsenic feeding and poisoning has been done from the physiological and pharmacological standpoint. It had been noticed by Hunter, Brodie and Home ${ }^{1}$ that arsenic, when applied to abraided surfaces, passed to the stomach where a specific action was noted. There are many contributions by Rutter, Hugo, ${ }^{2}$ Eulenberg, Geis, ${ }^{3}$ and others on the physiological action of the drug. Also Esser, Bintz and Arakie ${ }^{1}$ have studied the action of arsenic on the tissue. Orfila, Scolosuboff, ${ }^{4}$ Ludwig $^{5}$ and Chittenden ${ }^{6}$ have worked on the elimination and retention of the drug.

1 "Poisons, Their Effect and Detection." Blyth, I906.

${ }^{2}$ Ibid.

3 "Über den Einfluss des Arsens auf den Organismus," Arch. Path. Pharm., 8, i 82.

1 Bull. soc. chim. belg., 24, 124.

${ }^{5}$ Med. Jahrbuch., 1880.

${ }^{6} \mathrm{Am}$. Chem. J., $5,8$. 